\title{
Para perder-me à noite (pós-Colonial)
}

\author{
Josenilda Maués
}

Minha raça nasceu como nasceu o mar sem nomes, sem horizonte com seixos sob minha lingua, Com estrelas diferentes sobre mim

Será que derretemos espelhos adentro

Deixando nossas almas para trás?

Derek Walcott

Queria-me (e você, às avessas) borboleta nacarada

Desdenhar dessa genética paranóia persecutória

Que me guia o corpo loucura adentro - calmaria afora

E me escreve vozes - de objetos e gentes e tempos

E me desenha cheiros - de corpos - de textos de sons

E me oclude rostos - que só sei viver até o pescoço.

Ao mesmo tempo serva. Ao mesmo espaço autora

Prossigo indecidindo

Fazer da vida fluxo. Insistir no tempo rosário

Ou adivinhar o kairós que me esparge em festins.

Precisaria deter meus anseios diaspóricos

E catar meu corpo sem exilar meu peito

E experimentar aurática um tempo que me traga

$\mathrm{O}$ viver de tudo em pulsões atemporais

Josenilda Maués é graduada em Pedagogia pela UFPA; mestre e doutora em Educação: currículo pela PUC-SP. Professora da UFPA, onde atua no Programa de Pós-graduação em Gestão e Currículo da Escola Básica. Coordenadora adjunta do PARFOR/UFPA. Líder do Grupo de Pesquisa Diferença e Educação (DIFERE) que investe na realização de estudos voltados para a constituição de sínteses disjuntivas apoiadas nas virtualidades e multiplicidades de abordagens filosóficas de inspiração pós-estruturalista. Investe no aprofundamento do pensamento nômade da diferença como potência criadora para a composição do pensamento da diferença no âmbito do currículo e da formação de professores. 